\title{
Carboxyl terminal activating region 3 of latent membrane protein 1 encoded by the Epstein-Barr virus regulates cell proliferation and protein expression in NP69 cells
}

\author{
ZHI-WEI ZHANG ${ }^{1,2^{*}}$, HE-LIANG ZHANG ${ }^{1,3^{*}}$, YAN-HUI YU ${ }^{2}$, YONG-MEI OUYANG ${ }^{2}$, \\ ZHU-CHU CHEN ${ }^{2,4}$, XIU-SHENG HE ${ }^{1}$ and ZHI-MIN HE ${ }^{2,5}$
}

${ }^{1}$ Cancer Research Institute of Medical College, University of South China, Key Laboratory of Cancer Cellular and Molecular Pathology of Hunan, Hengyang, Hunan 421001; ${ }^{2}$ Cancer Research Institute, Central South University, Xiangya School of Medicine, Changsha, Hunan 410078; ${ }^{3}$ Medical Company, Troops 66028 of The People's Liberation Army, Chengde, Hebei 067000; ${ }^{4}$ Key Laboratory of Cancer Proteomics of Chinese Ministry of Health, Xiangya Hospital, Central South University, Changsha, Hunan 410078; ${ }^{5}$ Cancer Research Institute, Guangzhou Medical University, Guangzhou, Guangdong 510000, P.R. China

Received November 10, 2017; Accepted April 23, 2018

DOI: $10.3892 / \mathrm{mmr} .2019 .10859$

\begin{abstract}
In the present study, the mechanism by which carboxyl terminal activating region 3 (CTAR3) of latent membrane protein 1 (LMP1), encoded by the Epstein-Barr virus, regulated cell proliferation and protein expression was investigated in the nasopharyngeal epithelial cell line NP69. The deletion mutant LMP1 (LMP1 ${ }^{\triangle 232-351}$; amino acid residues including 232-351 codons in CTAR3 deleted) was generated by polymerase chain reaction. An NP69-LMP1 ${ }^{\Delta 232-351}$ cell line was established by retroviral infection. Finally, cell proliferation and protein expression of NP69 cells expressing LMP1 ${ }^{\Delta 232-351}$ were examined using a cell growth curve and western blot analysis. The results demonstrated: i) The proliferation of NP69-LMP1 $1^{\Delta 232-351}$ cells was significantly decreased compared with cells expressing wild type LMP1 (LMP1 ${ }^{\mathrm{WT}}$; $\mathrm{n}=3$; $\left.\mathrm{P}<0.05\right)$; ii) 17 proteins exhibited differential protein expression ( $>2$-fold change) in NP69-LMP1 ${ }^{\Delta 232-351}$ cells compared with NP69-LMP1 ${ }^{\text {WT }}$ cells; and iii) $\mathrm{LMP} 1^{\mathrm{WT}}$ was involved in activating the Janus
\end{abstract}

Correspondence to: Dr Zhi-Min He, Cancer Research Institute, Central South University, Xiangya School of Medicine, 110 Xiangya Road, Changsha, Hunan 410078, P.R. China

E-mail: hezhimin2005@yahoo.com

Dr Xiu-Sheng He, Cancer Research Institute of Medical College, University of South China, Key Laboratory of Cancer Cellular and Molecular Pathology of Hunan, 28 Changsheng Road, Hengyang, Hunan 421001, P.R. China

E-mail: hexiusheng@hotmail.com

${ }^{*}$ Contributed equally

Key words: latent membrane protein 1, carboxyl terminal activating region 3, NP69, cell proliferation, proteome, Janus kinase 3 kinase 3 (JAK3) promoter and regulating the expression of JAK3 protein, while LMP1 $1^{\Delta 232-351}$ was almost defective in ability to activate the JAK promoter. These results suggested that LMP1-CTAR3 may be an important functional domain for regulating cell proliferation and protein expression in nasopharyngeal epithelial cells.

\section{Introduction}

Epstein Barr-virus (EBV) is a highly prevalent $\gamma$ herpes virus in humans, and was also the first identified human tumor-associated virus (1). EBV is frequently implicated in the etiology of a number of malignancies, including nasopharyngeal carcinoma (NPC) (1). NPC, particularly poorly differentiated or undifferentiated NPC, is closely associated with EBV. Latent membrane protein 1 (LMP1) is known to be a oncogenic protein encoded by the EBV genome, as it has an important role in EBV-mediated B-cell proliferation and immortalization (2); however, the mechanism of LMP1-mediated epithelial cell transformation remains unclear. LMP1 is a 386 amino acid transmembrane glycoprotein, which consists of a short cytoplasmic N-terminal domain (residues 1-23), six transmembrane domains (residues 24-186), and a long cytoplasmic C-terminal domain (residues 187-386), which is known as the carboxyl terminal activation region (CTAR) (3). Currently, three CTARs have been reported, CTAR1 (residues 194-232), CTAR2 (residues 351-386) and CTAR3 (residues 275-330) (4). CTAR1 engages tumor necrosis factor receptor-associated factors to induce low-level nuclear factor- $\kappa \mathrm{B}(\mathrm{NF}-\kappa \mathrm{B})$ activation (5). CTAR2 interacts with TRA death domain protein to mediate high-level NF- $\kappa \mathrm{B}$ activation and also induces c-Jun N-terminal kinases/activator protein-1 (AP-1) activation (6). Gires et al (7) first reported the CTAR3 of LMP1 and confirmed the region was associated with the JAK3/signal transducer and activator of transcription (STAT) signaling pathway; however, its function in epithelial cells requires further analysis. 


\section{Materials and methods}

Plasmids. $\mathrm{NF}-\kappa \mathrm{B}$ luciferase (LUC) reporter and $\beta$-galactosidase plasmids were received from Dr David Goeddel (Tularik, Inc., San Francisco, CA, USA). AP-1 LUC reporter (with four AP-1 sites) was received from Dr Zhi-Gang Dong (University of Minnesota, Austin, MN, USA). pLNSX retroviral vector, $\mathrm{pLNSX}-\mathrm{LMP} 1^{\mathrm{WT}}$ retroviral vector (wild type with the full-length LMP1 gene) and pGL2 plasmids were received from Dr Liang Cao (University of Hong Kong, Hong Kong SAR, China).

Cell lines. The SV40-immortalized nasopharyngeal epithelial cell line NP69 was a generous gift from Dr Sai Wah Tsao (University of Hong Kong). NP69 cells were cultured in serum-free keratinocyte medium (K-SFM; Gibco; Thermo Fisher Scientific, Inc., Waltham, MA, USA) in humidified 5\% (v/v) $\mathrm{CO}_{2}$ atmosphere at $37^{\circ} \mathrm{C}$. Retrovirus packaging cell line PA317, immortalized lymphocyte cells and 293 cells were obtained from the American Type Culture Collection (Manassas, VA, USA), and routinely maintained in Dulbecco's modified Eagle's medium (Gibco; Thermo Fisher Scientific, Inc.) with $15 \%$ fetal calf serum (Gibco; Thermo Fisher Scientific, Inc.).

Reagents and primers. The mouse anti-human monoclonal antibody S12 for LMP1 (1:50) obtained from a hybridoma was a generous gift from Dr Liang Cao (University of Hong Kong, SAR, China). Immobilized $\mathrm{pH}$ gradient (IPG) strisp (pH 3-10NL, $24 \mathrm{~cm}$ ) were obtained from GE Healthcare (Chicago, IL, USA). Polymerase chain reaction (PCR) primers (Table I) were designed using Primer5 software (version 5.00; Premier Biosoft International, Palo Alto, CA, USA) and synthesized by Invitrogen (Thermo Fisher Scientific, Inc.).

Reorganization of the pLNSX-LMP1 $1^{4232-351}$ plasmid and pGL2/Janus kinase 3 (JAK3)-LUC plasmid. To construct an pLNSX-LMP1 ${ }^{\Delta 232-351}$ plasmid expressing a product with deleted amino acid residues at positions 232 to 351 in the CTAR3 region, plasmid pLNSX-LMP1 ${ }^{\text {WT }}$ with full-length LMP1 ${ }^{\text {WT }}$ gene as a template and four primers (p1, 5'CTCGGC CTCTGAGCTATTCC3'; p2, 5'GCCGCCATGGGCTCC ACTCACTCACGAGCAG3'; p3, 5'AGTGGAGCCCATGGC GGCGGTGACCCA3' and p4, 5'CGAGAAGCGAACTGA TTGGT3') were put into the PCR instrument (Eppendorf, Hamburg, Germany). The $50 \mu \mathrm{l}$ PCR reaction was carried out using a PCR amplification kit (Promega (Beijing) Biotech Co., Ltd, Beijing, China) according to the manufacturer's protocol. PCR was performed for 30 cycles and consisted of denaturation at $94^{\circ} \mathrm{C}$ for one minute, annealing at $58^{\circ} \mathrm{C}$ for $1 \mathrm{~min}$ and extension at $72^{\circ} \mathrm{C}$ for $1 \mathrm{~min}$. The PCR product and the pLNSX retroviral vector containing $\mathrm{XbaI}$ and HindIII sites were mixed in $10 \mu 1 \mathrm{PCR}$ reaction system at $1: 1$ ratio. The connection reaction was run overnight at $16^{\circ} \mathrm{C}$. The pLNSX-LMP1 $1^{\Delta 232-351}$ was confirmed by DNA sequencing. In addition, to construct the JAK3 LUC reporter plasmid, genomic DNA of immortalized lymphocyte cells was used as the PCR template with upstream primer (5'CCGCTCGAGGTGCCCAACTCACACATGCTA CAGAT3', the XhoI site denoted by bold font) and downstream primer (5'CCCAAGCTTAGAGGAAAGTCCCACTCGGCT CCTT3', the HindIII site denoted by bold font). PCR was performed for 35 cycles consisting of denaturation at $94^{\circ} \mathrm{C}$ for one minute, annealing at $63^{\circ} \mathrm{C}$ for $1 \mathrm{~min}$ and extension at $72^{\circ} \mathrm{C}$ for $30 \mathrm{sec}$. Subsequently, the PCR product was digested with HindIII and $\mathrm{XhoI}$ and cloned into the luciferase reporter plasmid pGL2. The pGL2/JAK3-LUC plasmid was obtained and confirmed by DNA sequencing.

Retrovirus-mediated gene transfer and detection of the expressed proteins. PA317 cells were transfected with pLNSX-LMP1 $1^{\mathrm{WT}}$ and pLNSX-LMP1 ${ }^{\Delta 232-351}$ at $300 \mathrm{ng} / \mathrm{well}$, to produce amphotropic retroviruses at a density of $5 \times 10^{4}$ cells per well in 6-well plates. After $24 \mathrm{~h}$ of transfection, the transfected PA317 cells were selected with G418 (500 mg/ml, Invitrogen; Thermo Fisher Scientific, Inc.). After 2-3 weeks, the resistant cells were collected and cultured as the virus-producing cell lines. NP69 cells, which were inoculated onto 6-well plates in triplicate at $5 \times 10^{4}$ cells/well, were transduced with Rv-LMP1 ${ }^{\mathrm{WT}}$, Rv-LNSX-LMP1 ${ }^{\triangle 232-351}$ retroviruses $(\mathrm{MOI}=30)$. After $48 \mathrm{~h}$, the successfully infected cells were selected by G418 $(400 \mu \mathrm{g} / \mathrm{ml})$ for 2 weeks, and the resistant clones were pooled and designated as NP69-LMP1 ${ }^{\text {WT }}$ and NP69-LMP1 $1^{\Delta 232-351}$ cells. The stable expression of LMP1 in the resistant clones was determined by western blotting and immunofluorescence assay with LMP1 antibody S12.

Immunofluorescence assay. Cell slides were prepared, fixed with methanol and acetone $(1: 1)$ at $4^{\circ} \mathrm{C}$ for $30 \mathrm{~min}$, washed, dried, and labeled with anti-LMP1 monoclonal antibody $\mathrm{S} 12$ (1:50) for $1 \mathrm{~h}$ at $37^{\circ} \mathrm{C}$. After washing, the cells were incubated with a FITC-labeled goat anti-mouse secondary antibody (1:500; cat. no. A-11029; Zymed; Thermo Fisher Scientific, Inc.) for $1 \mathrm{~h}$ at $37^{\circ} \mathrm{C}$, washed and then oil sealed and observed under a fluorescence microscope at $778 \mathrm{~nm}\left(\right.$ EVOS $^{\circledR}$ FL Auto; Thermo Fisher Scientific, Inc.).

Cell growth curve analysis. For growth curve analysis, transduced NP69 cells were seeded onto 96-well plates in triplicate wells at $1 \times 10^{4}$ cells/well at $24 \mathrm{~h}$ after viral infection. The number of viable cells was determined every $48 \mathrm{~h}$ using the MTT method. After incubation with MTT in a humidified $5 \%(\mathrm{v} / \mathrm{v}) \mathrm{CO}_{2}$ atmosphere at $37^{\circ} \mathrm{C}$ incubator for $4 \mathrm{~h}$, the cell culture supernatant was removed, $150 \mu \mathrm{l}$ of DMSO was added to fully dissolve the crystals and the OD value of each well was measured at a wavelength of $490 \mathrm{~nm}$ using an ELX800 microplate reader (BioTek China, Beijing, China). Growth curves were produced by plotting the mean and standard deviation of three independent experiments.

Soft agar clone formation assay. To determine the anchorage-independence ability of NP69 cells, LMP1 cells that had been transduced for $24 \mathrm{~h}$ were seeded into semisolid agar K-SFM medium [base layer, $0.6 \%$ (w/v); upper layer, $0.3 \%$ $(\mathrm{w} / \mathrm{v})]$ at a density of $5 \times 10^{4}$ cells per well in 6 -well plates. Three independent experiments with duplicate wells for each cell line were performed. After 3-4 weeks of incubation at $37^{\circ} \mathrm{C}$ with $5 \%(\mathrm{v} / \mathrm{v}) \mathrm{CO}_{2}$, the number and size of colonies ( $\geq 50$ cells was classed as one colony) were observed under an inverted microscope (TS100; Nikon Corporation, Tokyo, Japan), and 10 low power fields $(\mathrm{x} 4)$ were randomly selected for each group. The experiments were conducted in triplicate. 
Table I. Primer sequences used in fluorescent reverse transcription-quantitative polymerase chain reaction.

\begin{tabular}{|c|c|c|}
\hline Primers & Sequence $\left(5^{\prime}-3^{\prime}\right)$ & Product size (bp) \\
\hline \multirow[t]{2}{*}{ Ribosomal protein $\mathrm{P} 0$} & Sense AAGGCTGTGGTGCTGATG & 132 \\
\hline & Antisense GTCCTCCTTGGTGAACACA & \\
\hline \multirow[t]{2}{*}{ Annexin A2 } & Sense ATCTCTATGACGCTGGAGTGAA & 121 \\
\hline & Antisense GGGCTGTAACTCTTGTACCTATCA & \\
\hline \multirow[t]{2}{*}{ Heterogeneous nuclear ribonucleoprotein $\mathrm{A} / \mathrm{B}$} & Sense CTGGATGGCCGTGTCATT & 143 \\
\hline & Antisense GCCTCAATCTCCCCAAACT & \\
\hline \multirow{2}{*}{ Isocitrate dehydrogenase 3} & Sense TGCAGAGTATCAAGCTCATCAC & 143 \\
\hline & Antisense TAGAAAAAGCCCATCTGACATC & \\
\hline \multirow[t]{2}{*}{ G protein } & Sense GGGTCACTCCCACTTTGTTAG & 149 \\
\hline & Antisense TCAGCACATCCTTGGTATGG & \\
\hline \multirow[t]{2}{*}{$\beta$-actin (internal control) } & Sense ACCGTGGAGAAGAGCTACGA & 309 \\
\hline & Antisense GTACTTGCGCTCAGAAGGAG & \\
\hline
\end{tabular}

Preparation of the total protein sample. Harvested cells were washed twice with ice-cold PBS, and lysed in lysis buffer [7 mol/1 urea, $2 \mathrm{~mol} / \mathrm{l}$ thiourea, $2 \%$ (v/v) NP-40, $1 \%$ (v/v) Triton $\mathrm{X}-100,100 \mathrm{mmol} / \mathrm{l}$ dithiothreitol (DTT), $5 \mathrm{mmol} / \mathrm{l} \mathrm{PMSF}, 4 \%$ (w/v) CHAPS, $0.5 \mathrm{mmol} / 1$ EDTA, $40 \mathrm{mmol} / 1 \mathrm{Tris}, 1 \mathrm{mg} / \mathrm{ml}$ DNase I]. The cell lysates were incubated at $4^{\circ} \mathrm{C}$ for $30 \mathrm{~min}$ and then centrifuged at $4^{\circ} \mathrm{C}$ and $21,130 \mathrm{x}$ g for $10 \mathrm{~min}$. The supernatant constituted the total protein solution. The concentration of the total proteins was assayed with a 2D Quantification kit (GE Healthcare).

IPG-2D PAGE and image analysis. IPG-2D PAGE was performed according to the manufacturer's protocols (GE Healthcare). Protein samples $(1.0 \mathrm{mg})$ were diluted to $450 \mu \mathrm{l}$ with rehydration solution [8 mol/l urea, $2 \%(\mathrm{w} / \mathrm{v})$ CHAPS, $0.5 \%$ (v/v) pH 3-10 IPG buffer and trace bromophenol blue], and applied for isoelectric focusing (IEF) using Immobiline IPG strips ( $\mathrm{pH} 3-10$; L 240x3x0.5 mm). The strips were rehydrated at $30 \mathrm{~V}$ for $14 \mathrm{~h}$ and proteins were focused successively for $1 \mathrm{~h}$ at $500 \mathrm{~V}, 1 \mathrm{~h}$ at $1,000 \mathrm{~V}$ and $8.5 \mathrm{~h}$ at $8,000 \mathrm{~V}$ to produce a total of $69,920 \mathrm{Vh}$ on an IPGphor (Amersham Biosciences, Uppsala, Sweden). Following IEF, the IPG strips were equilibrated for $15 \mathrm{~min}$ at room temperature in a buffer containing $50 \mathrm{mM}$ Tris- $\mathrm{HCl}$ (pH 8.8), 30\% (v/v) glycerol, $6 \mathrm{M}$ urea, $2 \%$ $(\mathrm{w} / \mathrm{v})$ SDS and $1 \%(\mathrm{w} / \mathrm{v})$ DTT, followed by further treatment in a similar buffer [containing $2.5 \%(\mathrm{w} / \mathrm{v})$ iodoacetamide instead of DTT] for $15 \mathrm{~min}$, and then directly applied on to $12.5 \%(\mathrm{w} / \mathrm{v})$ homogeneous SDS-PAGE gels for electrophoresis using a the Ettan DALT II system (Amersham Biosciences, Uppsala, Sweden) according to the manufacturer's protocols. The separated proteins were visualized after $13 \mathrm{~h}$ Coomassie Brilliant Blue G-250 staining at room temperature. The stained 2D gels were scanned with MagicScan software (version 6.0; Kenxen Limited, Hong Kong, SAR, China) on an Imagescanner (Amersham Biosciences, Uppsala, Sweden) with 300 DPI resolution. The scanned data were then analyzed using PDQuest 2D gel analysis software (version 7.1; Bio-Rad Laboratories, Inc., Hercules, CA, USA). To ensure experiment reproducibility, the $2 \mathrm{D}$ gel of each cell line was repeated in triplicate. The gel spot pattern of each gel was summarized in a standard following spot matching. Thus, one standard gel for each cell line was established. The criteria to determine differential protein spots were that spot intensity increased or decreased more than two-fold between the comparison groups. Statistical analysis was performed using SPSS, version 18.0 (SPSS, Inc. Chicago, IL, USA).

Matrix assisted laser desorption/ionization-time of flight mass spectrometry (MALDI-TOF MS). A total of 39 differential protein spots were excised from preparative 2D gels using biopsy punches and transferred to a $1.5 \mathrm{ml}$ siliconized Eppendorf tube. Each spot was first washed with $50 \mu 1$ deionized water 3 times, each time for $2 \mathrm{~min}$. A further $50 \mu \mathrm{l}$ of decolorizing solution (100 mmol/ $\left.1 \mathrm{NH}_{4} \mathrm{HCO}_{3}, 30 \% \mathrm{CAN} ; 1: 1\right)$ was added at $37^{\circ} \mathrm{C}$ for $30 \mathrm{~min}$. The spot was then repeatedly rinsed with deionized water until the color had completely faded. A $300 \mu$ l volume of $100 \%$ CAN was added to dehydrate the sample before it was drained. A $5 \mu 1$ volume of trypsin working solution $(0.02 \mu \mathrm{g} / \mu \mathrm{l})$ was added to each tube to digest the sample at $4^{\circ} \mathrm{C}$ for $45 \mathrm{~min}$. After the solution had been completely absorbed by micelles, $30 \mu \mathrm{l}$ of $\mathrm{NH}_{4} \mathrm{HCO}_{3}$ ( $40 \mathrm{mmol} / \mathrm{l}$ ) was added and the sample was incubated at $37^{\circ} \mathrm{C}$ overnight. The supernatant was transferred to a new tube, and $30 \mu \mathrm{l}$ extraction liquid (60\% CAN, 5\% TFA; $1: 1)$ was added to the original tube, the extraction was repeated twice at $37^{\circ} \mathrm{C}$ for $60 \mathrm{~min}$. After extraction and enzymolysis the supernatants were combined and lyophilized to prepare the protein sample. The protein samples were analyzed by Applied Biosystems Voyager System 4307 MALDI-TOF mass spectrometer (Applied Biosystems; Thermo Fisher Scientific, Inc.). The parameters were set up as follows: Positive ion-reflector mode, accelerating voltage $20 \mathrm{kV}$, grid voltage $64.5 \%$, mirror voltage ratio $1.12, \mathrm{~N}_{2}$ laser wavelength $337 \mathrm{~nm}$, pulse width $3 \mathrm{nsec}$, the number of laser shots 50 , acquisition mass range 1,000-3,000 Da, delay $100 \mathrm{nsec}$ and vacuum degree $4 \times 10^{-7}$ Torr. A trypsin-fragment peak served as internal standard for mass calibration. A list of the corrected mass peaks was termed the peptide mass fingerprint (PMF). Proteins were identified from PMF data by searching the UniProt database (http://www.uniprot.org/uniprot) using the software MASCOT 
(version 2.5.1, Matrix Science, Ltd., London, UK). Subcellular location and function information was derived from the NCBI database (http://www.ncbi.nlm.nih.gov).

Protein extraction and western blot analysis. Cells were extracted in lysis buffer $(0.5 \%$ Nonidet $\mathrm{P}-40,5 \%$ sodium deoxycholate, $50 \mu \mathrm{M} \mathrm{NaCl}, 10 \mu \mathrm{M}$ Tris- $\mathrm{HCl}, \mathrm{pH} 7.5,1 \%$ bovine serum albumin) and centrifuged at $4^{\circ} \mathrm{C}$ and $18,407 \mathrm{x} \mathrm{g}$ for $15 \mathrm{~min}$. The supernatant was mixed with $2 \mathrm{X}$ loading buffer and boiled for $5 \mathrm{~min}$, and then the samples were separated via $10 \%$ SDS-PAGE gels and transferred to polyvinylidene difluoride membranes. The membranes were blocked with $5 \%$ fat-free milk at room temperature for $1 \mathrm{~h}$, incubated at $4^{\circ} \mathrm{C}$ overnight with antibodies S12 for LMP1 (1:50), anti- $\beta$-actin (1:10,000; cat. no. A1978; Sigma-Aldrich; Merck KGaA, Darmstadt, Germany), anti-G protein (1:500; cat. no. 371818; Sigma-Aldrich; Merck KGaA) and anti-heterogeneous nuclear ribonucleoprotein A/B (1:500; cat. no. sc-376411; Santa Cruz Biotechnology, Inc., Dallas, TX, USA), washed, and then incubated with peroxidase-conjugated secondary antibody (1:2,000; cat. no. sc-11001; Santa Cruz Biotechnology, Inc.). Immune complexes were detected using an Amersham ECL Western Blotting Detection kit (Amersham Pharmacia Biotech, Little Chalfont, UK) and gel imaging analysis (Cool Imager; Viagene Biotech, Inc). To confirm the expression levels of each protein examined in LMP1-transfected cells, western blotting for each protein was performed in triplicate.

RNA extraction and reverse transcription-quantitative polymerase chain reaction $(R T-q P C R)$ analysis. The gene expression of the differential proteins was quantitated by RT-qPCR using Roche Light Cycler system (Roche Diagnostics GmbH, Mannheim, Germany) and SYBR premix Ex Taq kit (Takara Bio, Inc., Otsu, Japan). The expression levels of $\beta$-actin served as an internal control. Total cellular RNA was isolated from NP69-LMP1 ${ }^{\mathrm{WT}}$ and NP69-LMP1 ${ }^{\triangle 232-351}$ cells using TRIzol $^{\circledR}$ (Thermo Fisher Scientific, Inc.), according to the manufacturer's protocol. RNA integrity was observed by electrophoresis with $1 \%$ agarose gel containing ethidium bromide. A total of $2 \mu \mathrm{g}$ DNase-treated RNA underwent RT to produce cDNA and $1 \mu 1 \mathrm{RT}$ product was used to amplify gene fragments. First-strand cDNA was synthesized from DNase-treated total RNA with oligo-dT primer and Super-Script II reverse transcriptase (Takara Bio, Inc.) for $60 \mathrm{~min}$ at $42^{\circ} \mathrm{C}$ and $10 \mathrm{~min}$ at $72^{\circ} \mathrm{C}$, followed by qPCR amplification using the corresponding specific primers (Table I). The qPCR cycling conditions were as follows: $95^{\circ} \mathrm{C}$ for $3 \mathrm{~min}$ followed by 50 cycles of $95^{\circ} \mathrm{C}$ for $30 \mathrm{sec}, 62^{\circ} \mathrm{C}$ (ribosomal protein $\mathrm{P} 0$ and isocitrate dehydrogenase 3 ) or $65^{\circ} \mathrm{C}$ (annexin $\mathrm{A} 2$, heterogeneous nuclear ribonucleoprotein $\mathrm{A} / \mathrm{B}$ and $\mathrm{G}$ protein) for $30 \mathrm{sec}$, and then $72^{\circ} \mathrm{C}$ for $30-40 \mathrm{sec}$. The relative fold change method (8) was used to determine the relative quantitative gene expression for each gene studied compared with the $\beta$-actin control. The relative fold change or relative gene expression value $2^{-\Delta \Delta \mathrm{Cq}}$, where $\Delta \Delta \mathrm{Cq}=\left[\left(\mathrm{Cq}_{\text {Target[LMP }}{ }^{\mathrm{WT}}{ }_{1]}-\mathrm{Cq}_{\beta \text {-actin [LMP1 }}{ }^{\mathrm{WT}}{ }_{]}\right)-\left(\mathrm{Cq}_{\text {Target[LMP1 }}{ }^{\Delta 232-351}\right.\right.$ $\left.\left.-\mathrm{Cq}_{\beta \text {-actin [LMP1 }}{ }^{\Delta 232-351}{ }_{1}\right)\right] . \mathrm{Cq}_{\text {Target [LMP }}{ }^{\mathrm{WT}}{ }_{\text {] }}=$ quantification cycle of the target gene examined in the LMP1-expressing cells; $\mathrm{Cq}_{\beta \text {-actin[LMP }}{ }^{\mathrm{WT}}{ }_{]}=$quantification cycle of the $\beta$-actin gene in the LMP1-expressing cells; $\mathrm{Cq}_{\text {Target [LMP1 }}{ }^{\Delta 232-351}$ ] = quantification cycle of the target gene examined in the LMP1 $1^{\Delta 232-351}$-expressing
Table II. Cell culture transformation analysis of NP69-pLNSX, NP69-LMP1 ${ }^{\text {WT }}$ and NP69-LMP1 ${ }^{\Delta 232-351}$.

Cells

Foci-forming number

NP69-LMP1 $1^{\Delta 232-351}$
NP69-LMP1 ${ }^{\text {wT }}$
NP69-pLNS $X$

$88 \pm 7^{\mathrm{a}}$

${ }^{\mathrm{a}} \mathrm{P}<0.05$ vs. NP69-LMP1 ${ }^{\mathrm{WT}}$. LMP1, latent membrane protein 1; WT, wild type; LMP1 ${ }^{\mathrm{D} 232-351}$, mutant type LMP1.

cells; and $\mathrm{Cq}_{\beta \text {-actin [LMP1 }}{ }^{\Delta 232-351}{ }_{\text {] }}=$ quantification cycle of the $\beta$-actin gene in the LMP1 ${ }^{\Delta 232-351}$-expressing cells. RT-qPCR analyses independently were performed in triplicate.

Transcription activity analysis. For each transfection, 293 cells were seeded into 6 -well dishes at $1 \times 10^{5}$ cells/well. The indicated amounts $(500,150,300,450$ or $600 \mathrm{ng} / \mathrm{well})$ of pLNSX, pLNSX-LMP1 or pLNSX-LMP1 ${ }^{\Delta 232-351}$ plasmids were co-transfected with $\beta$-gal (200 ng/well) and reporter plasmids (200 ng/well) of NF- $\mathrm{B}$, AP-1 or JAK3, respectively. Vector pLNSX was supplemented to a total amount of $1 \mu \mathrm{g}$ DNA for every well. Transfection was conducted with transfection reagent Lipofectamine ${ }^{\circledR} 2000$ (Invitrogen; Thermo Fisher Scientific, Inc.). Cell lysates were collected $24 \mathrm{~h}$ later and were examined with a luciferase assay system (Promega Corporation, Madison, WI, USA) according to the manufacturer's protocol, to obtain the relative activities of the promoter. Relative LUC values were calculated as the ratio of LUC vs. $\beta$-galactosidase activity. A total of three independent experiments were performed, and each experiment was performed in triplicate.

Statistical analysis. Data are presented as the mean \pm standard deviation for $\geq 3$ separate experiments. Statistical analyses were carried out with SPSS (version 10.01; SPSS, Inc., Chicago, IL, USA). Statistical analysis was performed using a Student's t-test or one-way analysis of variance followed by the Tukey multiple comparison test. $\mathrm{P}<0.05$ was considered to indicate a statistically significant difference.

\section{Results}

Identification of pLNSX-LMP1 ${ }^{4232-351}$ and pGL2/JAK3-LUC plasmids. To investigate the role of the CTAR3 binding site in LMP1-mediated JAK3 signaling, mutant LMP1 ${ }^{\triangle 232-351}$, LMP1 with amino acid residue deletion from 232 to 351, was constructed as described, and a JAK3 promoter reporter system was generated using qPCR. The construction of these plasmids was confirmed by enzyme digestion and agarose gel electrophoresis (Fig. 1). The resultant sequence was fully verified by sequencing (data not shown).

Lack of LMPI CTAR3 reduces the proliferation and growth of NP69 cells. In the present study, the two cell lines, NP69-LMP1 ${ }^{\text {WT }}$ and NP69-LMP1 ${ }^{\triangle 232-351}$ (Fig. 2A) were established. Then, the expression levels of LMP1 in NP69-LMP1 ${ }^{\text {WT }}$ 

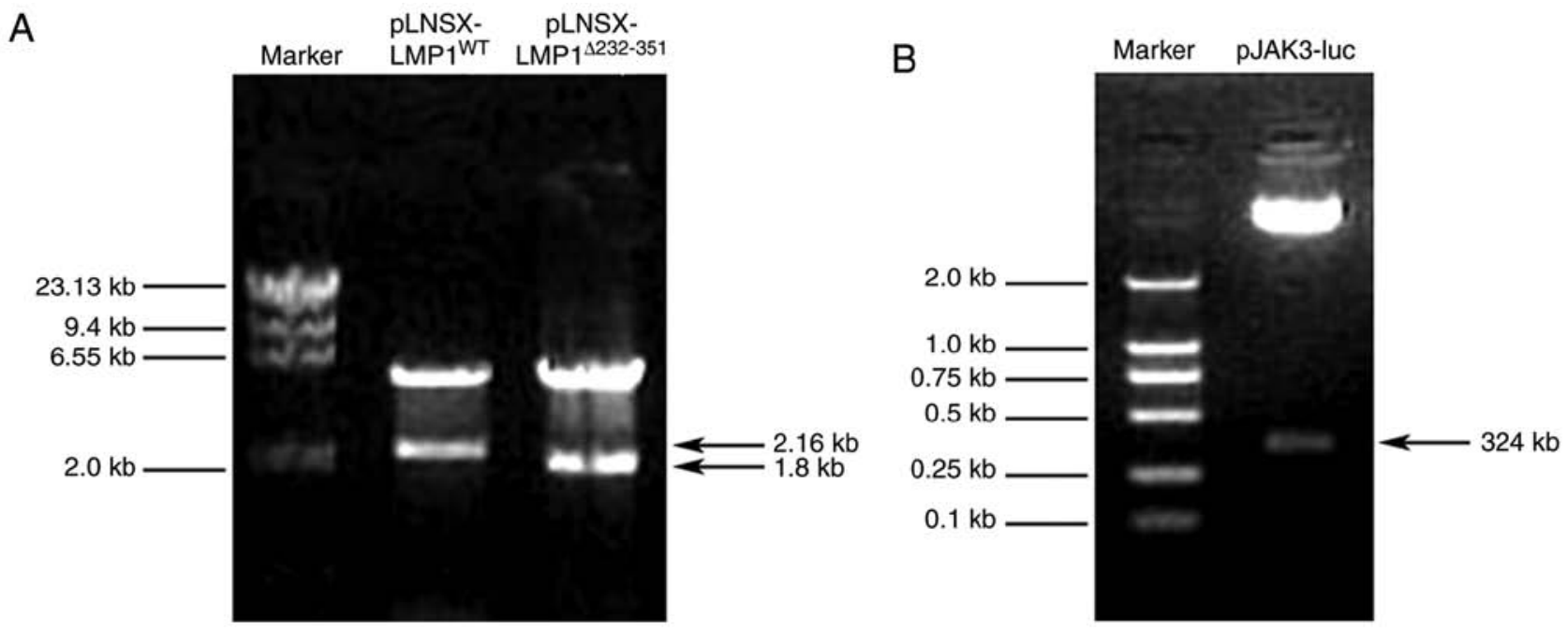

Figure 1. Recombination plasmid identification via enzyme digestion. (A) Recombinant pLNSX-LMP1 ${ }^{\Delta 232-351}$ plasmid was confirmed by HindIII and XbaI restrictive enzyme digesting analysis. (B) pJAK3-luc plasmid was digested by HindIII and XhoI restrictive enzyme. The enzyme digestion products were visualized by $1.0 \%$ agarose gels stained with ethidium bromide. LMP1, latent membrane protein 1; WT, wild type; LMP1 ${ }^{\Delta 232-351}$, mutant type LMP1; JAK3, Janus kinase 3 .

A

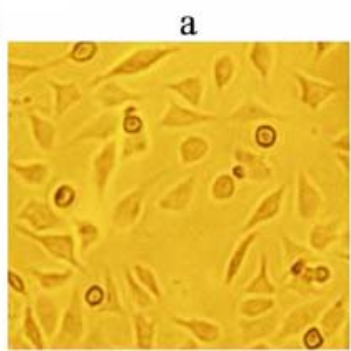

$\mathrm{C}$

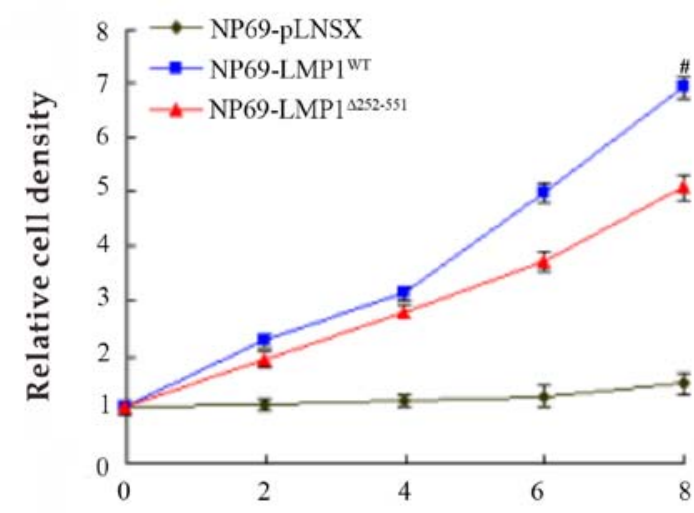

Days
$\mathrm{B}$

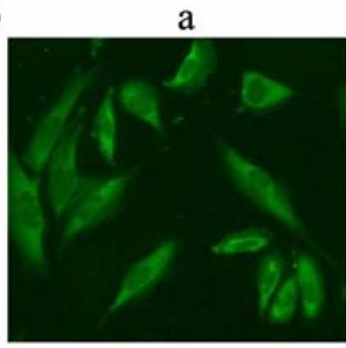

1

$\mathrm{D}$

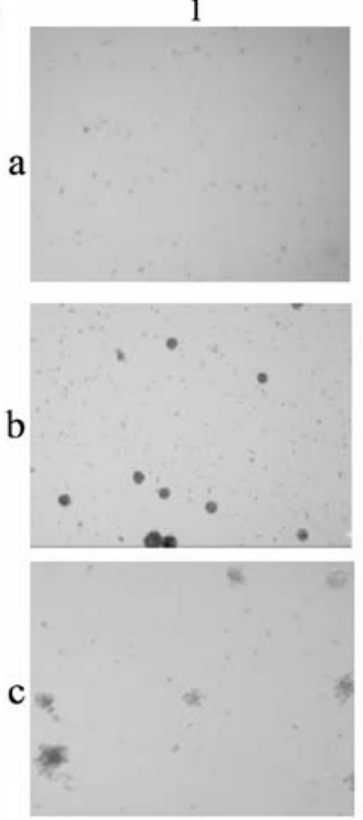

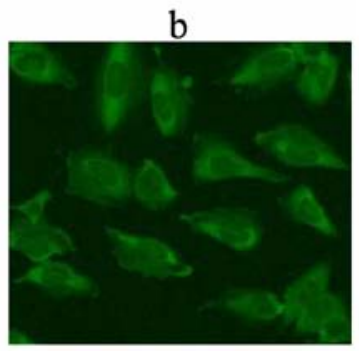

2
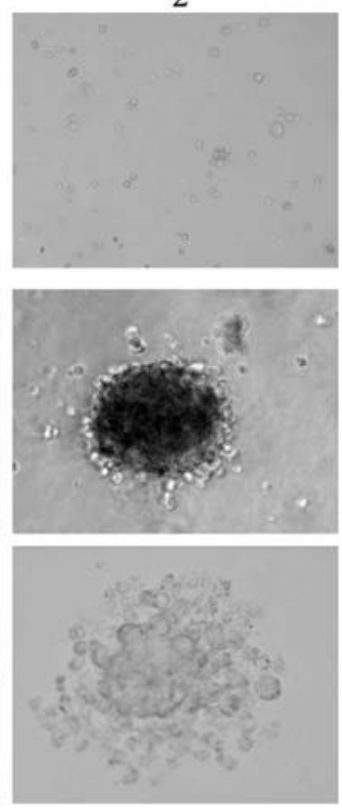

Figure 2. Biological properties of NP69-LMP1 ${ }^{\mathrm{wT}}$ and NP69-LMP1 ${ }^{\triangle 232-351}$ cell lines (magnification x400). (A) Morphologies of LMP1-expressed NP69 cells. (A-a) NP69-LMP $1^{\text {WT }}$ exhibited elongated and fibroblast-like shape. (A-b) NP69-LMP1 ${ }^{\triangle 232-351}$ exhibited similar with fibroblast-like shape. (B) Expression of LMP1 in NP69 cells was detected by immunofluorescence. (B-a) NP69-LMP1 ${ }^{\text {WT }}$ revealed green fluorescence, demonstrating LMP1 protein expression within the cellular membrane and cytoplasm. (B-b) NP69-LMP1 ${ }^{\Delta 232-351}$ also exhibited LMP1 protein expression. (C) Proliferation of NP69 cell lines expressing $\mathrm{LMP}^{\mathrm{WT}}$ and LMP1 ${ }^{\Delta 232-351}$. The NP69-LMP1 ${ }^{\mathrm{WT}}$ cells proliferated faster than NP69-LMP1 ${ }^{\Delta 232-351}$ cells. (D) Colonies of NP69 cells in soft agar. There was a marked difference in size and morphology of the soft agar clones between NP69-LMP1WT and NP69-LMP1 $\Delta 232-351$ cells. (D-a1, a2) NP69-pLNSX cells form very few colonies in soft agar. (D-b1, b2) The NP69-LMP1 ${ }^{\mathrm{WT}}$ soft agar clones were larger, less compact in organization and more irregular in shape. (D-c1, c2) The NP69-LMP1 $1^{\Delta 232-351}$ clones were smaller, closely packed and round in shape. Values are presented as the mean \pm standard deviation (n=3, ${ }^{\#} \mathrm{P}<0.05$ vs. NP69-LMP1 ${ }^{\Delta 232-351}$ ). LMP1, latent membrane protein 1; WT, wild type; LMP1 ${ }^{\Delta 232-351}$, mutant type LMP1. 

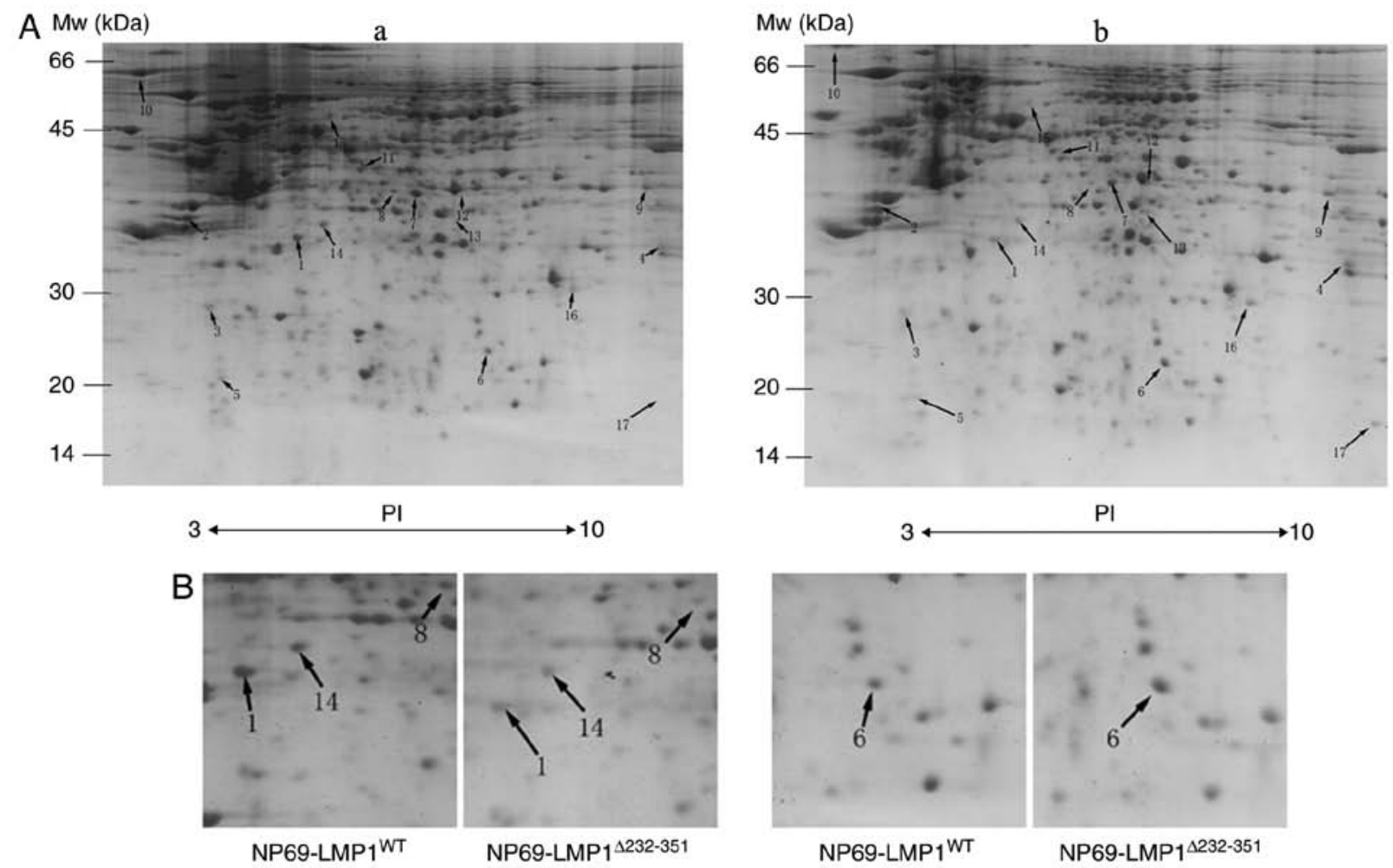

Figure 3. Immobilized $\mathrm{pH}$ gradient 2D electrophoresis of NP69-LMP1 ${ }^{\mathrm{WT}}$ and NP69-LMP1 ${ }^{\Delta 232-351}$ cells. (A) Arrows mark the differential protein spots. (A-a) A representative 2D gel map of NP69-LMP1 $1^{\mathrm{WT}}$ revealed 17 notable differential protein spots compared with (A-b) NP69-LMP1 ${ }^{\Delta 232-351}$. (B) Protein spots indicated by arrow were seen in both NP69-LMP1 ${ }^{\mathrm{WT}}$ and NP69-LMP1 ${ }^{\Delta 232-351}$. LMP1, latent membrane protein 1; WT, wild type; LMP1 ${ }^{\Delta 232-351}$, mutant type LMP1.

and NP69-LMP1 ${ }^{\Delta 232-351}$ cells were detected by immunofluorescence with antibody against LMP1 S12 (Fig. 2B). In addition, the growth curves of NP69-LMP1 ${ }^{\text {WT }}$ and NP69-LMP1 $1^{\Delta 232-351}$ $\left(n=3, P<0.05\right.$; Fig. 2C) were examined. NP69-LMP1 ${ }^{\text {WT }}$ cells exhibited a relatively faster growth rate with $\sim 7-8$ population doublings by day 8 compared with in control (NP69-pLNSX) cells. Conversely, NP69-LMP1 ${ }^{\Delta 232-351}$ cells only exhibited a growth rate of $\sim 4-5$ population doublings by day $8(\mathrm{P}<0.05$ vs. NP69-LMP1 ${ }^{\text {WT }}$ ). The anchorage-independent growth ability of NP69-LMP1 ${ }^{\mathrm{WT}}$ and NP69-LMP1 ${ }^{\Delta 232-351}$ cells was also compared. LMP1 ${ }^{\mathrm{WT}}$ and LMP1 $1^{\Delta 232-351}$ expression induced anchorage-independent growth in NP69 cells; however, the cloning efficiency of NP69-LMP1 ${ }^{\text {WT }}$ cells $(256 \pm 14$ clones) was $\sim 3$-fold higher than that of the NP69-LMP1 ${ }^{\triangle 232-351}$ cells $(88 \pm 7$ clones; $\mathrm{n}=3, \mathrm{P}<0.05$; Table II). In addition to the difference in cloning efficiency, there was a marked difference in size and morphology of the soft agar clones between NP69-LMP1 ${ }^{\text {WT }}$ and NP69-LMP1 ${ }^{\triangle 232-351}$ cells. The NP69-LMP1 ${ }^{\text {wT }}$ soft agar clones were larger, less compact in organization and more irregular in shape, while the NP69-LMP1 ${ }^{\triangle 232-351}$ clones were smaller, closely packed and round in shape (Fig. 2D). These results suggested that the CTAR3 of LMP1 has an important role on the proliferation and growth of NP69 cells.

Differential protein expression identified using IPG-2D PAGE in NP69-LMPI WT and NP69-LMP1 ${ }^{4232-351}$ cell lines. In the present study, two reproducible $2 \mathrm{D}$ gels for each transduced NP69 cell line were obtained. In the pH range 3-10, there were $1,088 \pm 43$ and $1,142 \pm 46$ protein spots observed in NP69-LMP1 ${ }^{\text {WT }}$ and NP69-LMP1 ${ }^{\Delta 232-351}$, respectively. For the matched counter-spots, the same position of spots was identified in the two images, which greatly facilitated the following comparison, as presented in magnified views of the 2D gel map. These differential protein spots were marked with arrows (Fig. 3A). Magnified regions of the gels revealed differential expression proteins (Fig. 3B). The quantification of the protein spots, analyzed by PDQuest software, revealed that some protein spots exhibited variable expression levels in the two cell lines, as indicated by staining intensities. A total of 17 protein spots exhibited $>2$-fold change in NP69-LMP1 ${ }^{\Delta 232-351}$-expressing cells compared with NP69-LMP1 ${ }^{\mathrm{WT}}$-transduced cells.

Identification of differential protein spots. Following spot excising and tryptic digestion, identification of the protein of interest was performed using MALDI-TOF MS. The expectation value for proteins was determined via PMF by using the MASCOT program. The 17 differential protein spots between NP69-LMP1 ${ }^{\text {WT }}$ and NP69-LMP1 ${ }^{\triangle 232-351}$ were identified with details summarized in Table III; 8 upregulated and 9 downregulated proteins were associated with structural proteins, metabolic enzymes, repair of DNA damage, energy and electron transport, transcription and translation, molecular chaperone, immunoregulation and calcium-binding, according to UNIPROT and NCBI database.

Validation of the results of partial identified proteins by RT-qPCR and western blotting. The mRNA expression levels of differentially expressed proteins were confirmed by RT-qPCR analysis (data not shown). The results of RT-qPCR analysis coincided with the data of the $2 \mathrm{D}$ gel. Within 


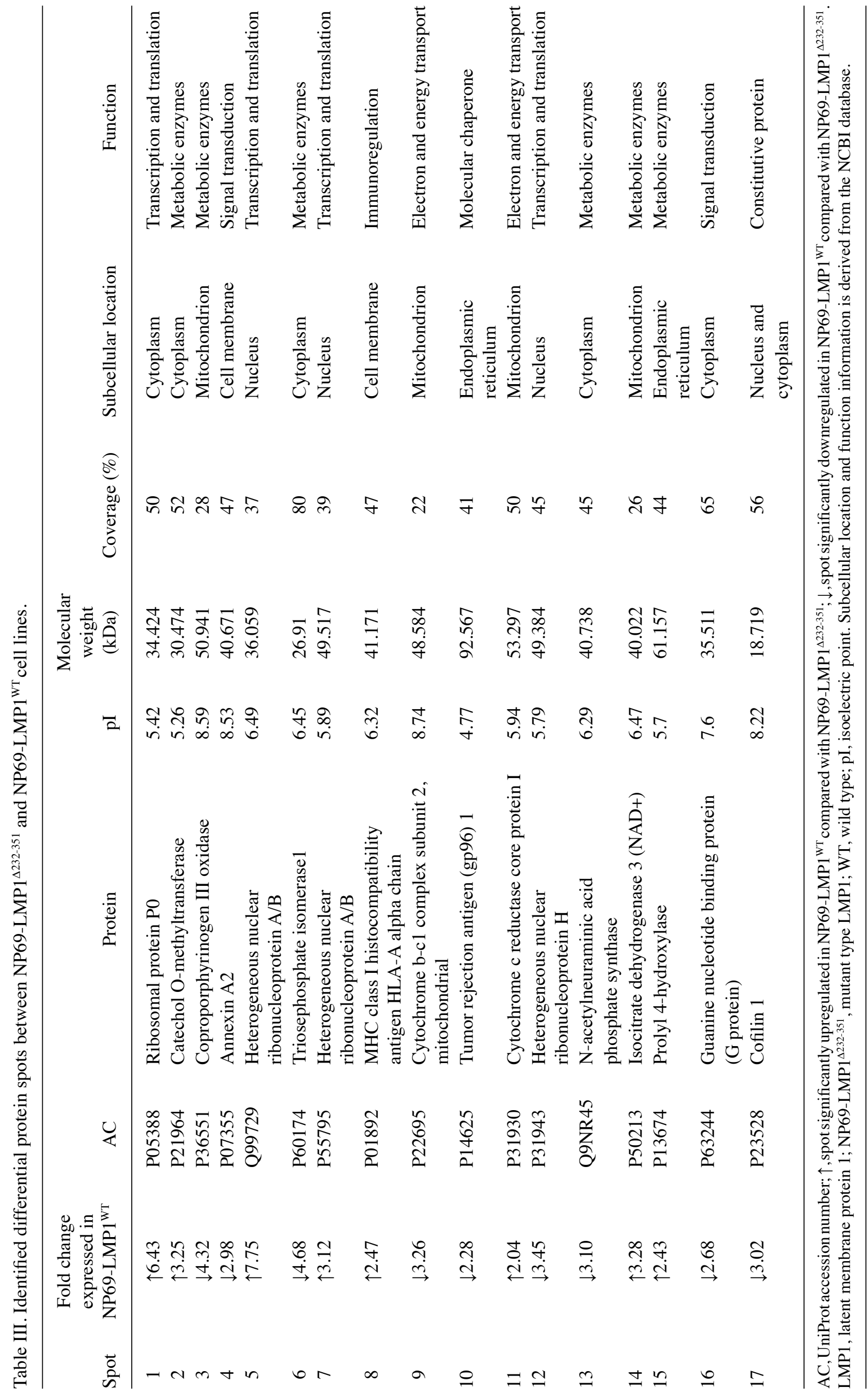


A
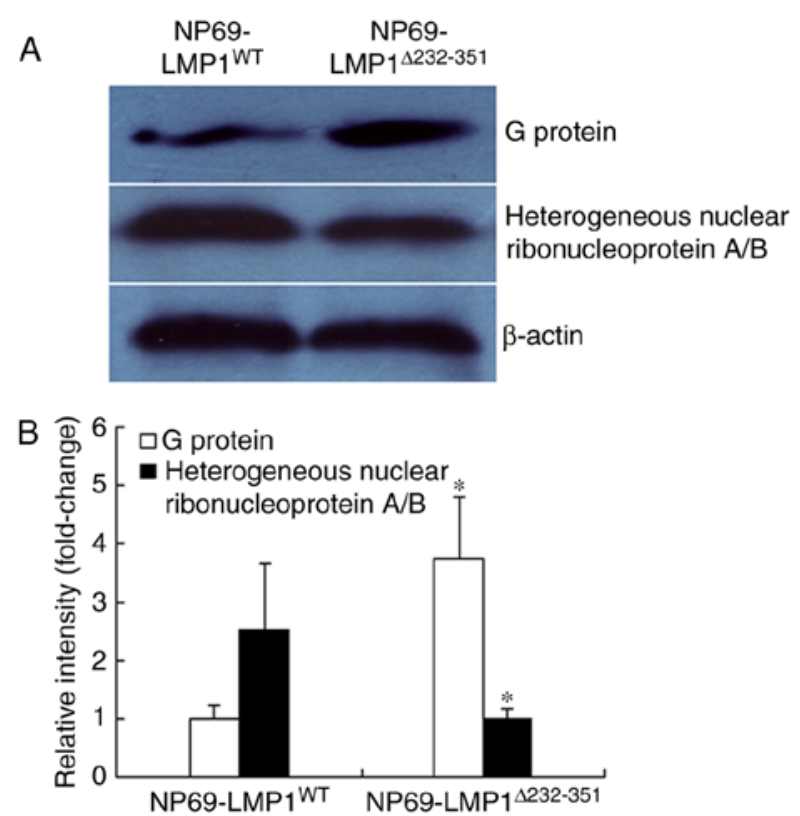

Figure 4.Expression of $\mathrm{G}$ protein and heterogeneous nuclear ribonucleoprotein A/B detection via western blotting. (A) Compared with NP69-LMP1 $1^{\Delta 232-351}$ cells, the expression levels of $\mathrm{G}$ protein were downregulated but the expression levels of heterogeneous nuclear ribonucleoprotein $\mathrm{A} / \mathrm{B}$ were upregulated in NP69-LMP1 ${ }^{\mathrm{WT}}$ cells. (B) Compared with NP69-LMP1 ${ }^{\mathrm{WT}}$ cells, the expression levels of $\mathrm{G}$ protein were upregulated in NP69-LMP1 $1^{\Delta 232-351}$. Densitometry analysis indicated that the expression of $\mathrm{G}$ protein and heterogeneous nuclear ribonucleoprotein $\mathrm{A} / \mathrm{B}$ was significantly differential between NP69-LMP1 $1^{\Delta 232-351}$ and NP69-LMP1 ${ }^{\mathrm{WT}}\left(\mathrm{n}=3,{ }^{*} \mathrm{P}<0.05\right.$ vs. NP69-LMP1 $\left.{ }^{\mathrm{WT}}\right)$. LMP1, latent membrane protein 1; WT, wild type; LMP1 ${ }^{\Delta 232-351}$, mutant type LMP1.

NP69-LMP1 ${ }^{\mathrm{WT}}$-transduced cells, the mRNA expression levels of ribosomal protein $\mathrm{P} 0$ and heterogeneous nuclear ribonucleoprotein $\mathrm{A} / \mathrm{B}$ were increased by 5.31- and 6.45 -fold, respectively (Table IV), compared with NP69-LMP1 ${ }^{\Delta 232-351}$. Two proteins, heterogeneous nuclear ribonucleoprotein A/B (greatest fold change increase) and $\mathrm{G}$ protein (2.07-fold change) were selected from the list of differentially expressed proteins for validation by western blotting, which reflected a similar pattern of expression to those observed in the IPG-2D gel analysis. Compared with NP69-LMP1 $1^{\Delta 232-351}$, NP69-LMP1 ${ }^{\text {WT }}$ exhibited a significant increase in heterogeneous nuclear ribonucleoprotein A/B and decrease of $\mathrm{G}$ protein $(n=3$; $\mathrm{P}<0.05$; Fig. 4). These results validated the expression pattern of proteins identified from the $2 \mathrm{D}$ gel analysis.

CTAR3 of LMPI activates the JAK3 signaling pathway. To investigate the mechanism by which LMP1 may regulate the JAK3 signaling pathway, the NF- $\mathrm{KB}$, AP-1 or JAK3 luciferase reporters were co-transfected with wild type LMP1 or mutant LMP1 $1^{\Delta 232-351}$ plasmid into 293 cells. The results demonstrated that the ability of mutant LMP1 ${ }^{\Delta 232-351}$ in inducing transcriptional activity of NF- $\kappa \mathrm{B}$ or AP-1 LUC reporter plasmids was similar to wild type LMP1 (Fig. 5A and B). Additionally, the transcriptional activity of the JAK3 promoter was upregulated by wild type LMP1, and the extent of upregulation was associated with the concentration of wild type LMP1; however, mutant LMP1 ${ }^{\Delta 232-351}$ was almost defective in activation of JAK3 reporter transcription (Fig. 5C). The results of the present study suggested that LMP1 may participate in the activation of
Table IV. Relative mRNA expression level in cancer-associated proteins differentially expressed between NP69-LMP $1{ }^{\mathrm{WT}}$ and NP69-LMP1 ${ }^{\Delta 232-351}$ cell lines.

Fold change expressed $^{\mathrm{a}}$

Gene in NP69-LMP1 ${ }^{\text {WT }}$

Ribosomal protein $\mathrm{P} 0$

$5.31 \pm 0.23$ fold increase

Annexin A2

$2.30 \pm 1.20$ fold decrease

Heterogeneous nuclear

$6.45 \pm 0.49$ fold increase

ribonucleo protein $\mathrm{A} / \mathrm{B}$

Isocitrate dehydrogenase 3

$2.21 \pm 0.13$ fold increase

G protein

$2.07 \pm 0.47$ fold decrease

${ }^{\mathrm{a}}$ Fold change in NP69-LMP1 ${ }^{\mathrm{WT}}$ vs. NP69-LMP1 ${ }^{\Delta 232-351}$. LMP1, latent membrane protein 1 ; WT, wild type; NP69-LMP1 $1^{\triangle 232-351}$, mutant type LMP1.

the JAK3 signaling pathway, associated with JAK3 promoter activation via LMP1. Therefore, the results indicated that the CTAR3 of LMP1 may be a key domain required for activating the JAK3 promoter.

\section{Discussion}

EBV is a highly prevalent $\mathrm{g}$ herpes virus associated with NPC and Burkett's lymphoma, and LMP1 was known generally for critical oncogenic protein coded by EBV genome $(1,9,10)$. The studies that verified the expression of LMP1 in the majority of NPC tissues suggested that LMP1 may be closely associated with NPC genesis and invasion; however, further investigation is required (11,12). Tsao et al and Lo et al established the NP69 normal immortalization nasopharyngeal epithelium cell line in vitro, and reported that the cell generated a serial malignant phenotype when a LMP1 eukaryotic expression vector was introduced into the NP69 cell line $(13,14)$. Gires et al (7) first reported the CTAR3 of LMP1 and confirmed the region was associated with the JAK3/signal transducer and activator of transcription (STAT) signaling pathway; however, its function in epithelial cells requires further analysis. To further investigate the functional activity of LMP1-CTAR3, a retrovirus was used to establish an NP69 cell line with stable expression of mutant LMP1 $1^{\triangle 232-351}$ and wild type LMP1 ${ }^{\mathrm{WT}}$, respectively named NP69-LMP1 $1^{\triangle 232-351}$ and NP69-LMP1 ${ }^{\text {WT }}$ cells in the present study. Subsequently, the biological properties of transfected NP69 cells were observed. Collectively, the results of the present study supported the findings of Tsao et al (13), which demonstrated that LMP1 promoted NP69 cell proliferation and transformation, increased cell growth velocity and increased multiple clone formation.

Previously, numerous studies reported the role of LMP1 transforming animal, human fibroblasts and some immortalization epithelial cells (14-16). In the present study, the results further supported the hypothesis that LMP1 may be associated with several malignancies of epithelium origin, such as NPC. In the current study, the ability of mutant LMP1 $1^{\Delta 232-351}$ to promote proliferation was notably reduced compared with LMP $1{ }^{\mathrm{WT}}$. These results suggested that CTAR3 may participate 

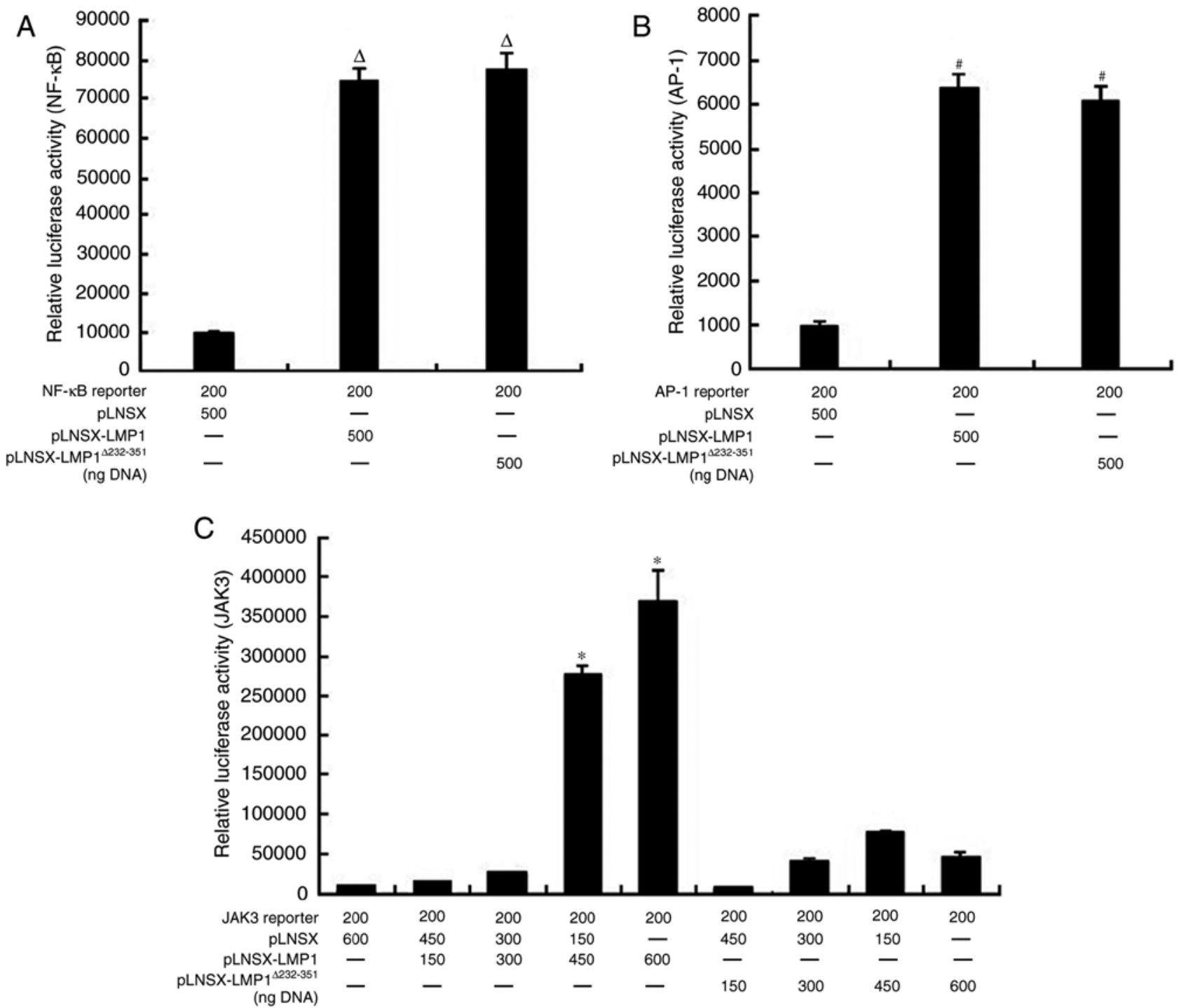

Figure 5. Ability of LMP1 protein to activate transcriptional activity of NF- $\mathrm{KB}, \mathrm{AP}-1$ and JAK3 promoters (A) Mutant LMP1 $1^{\Delta 232-351}$ and LMP1 ${ }^{\mathrm{WT}}$-induced expression of the NF- $\kappa B$ reporter in 293 cells $\left(n=3,{ }^{\wedge} \mathrm{P}<0.05\right.$ vs. pLNSX). (B) Mutant LMP1 ${ }^{\Delta 232-351}$ and $L M P 1^{\mathrm{WT}}$-induced expression of the AP-1 reporter in 293 cells ( $\mathrm{n}=3,{ }^{\text {"P }} \mathrm{P}<0.05$ vs. pLNSX). (C) Mutant LMP1 ${ }^{\Delta 232-351}$ did not significantly induce the transcription of the JAK3 reporter within 293 cells, compared with $\mathrm{LMP}^{\mathrm{WT}}\left(\mathrm{n}=3,{ }^{*} \mathrm{P}<0.05\right.$ vs. pLNSX and pLNSX-LMP1 $\left.{ }^{\Delta 232-351}\right)$. Values are presented as the mean \pm standard deviation. NF- $\mathrm{kB}$, nuclear factor- $\kappa \mathrm{B} ; \mathrm{LMP} 1$, latent membrane protein 1; WT, wild type; LMP1 ${ }^{\Delta 232-351}$, mutant type LMP1; AP-1, activator protein-1; JAK3, Janus kinase 3.

in the regulation of LMP1 associated with cell proliferation; however, whether CTAR3 is involved in JAK3/STAT3 signaling pathway requires further investigation. It has been reported that the phosphorylation of JAK3 mediates the regulation of cell proliferation (17). Therefore, LMP1-CTAR3 may activate the JAK3/STAT signaling pathway in nasopharynx epithelial cells.

Studies have reported on the role of LMP1 in the promotion of cell transformation $(18,19)$, however to elucidate the underlying mechanism will require further research. In addition, the signaling pathway of interest, in particular the function and feature of CTAR3, lacked unified recognition and conclusion. In the present study, the protein molecule network associated with wild type $\mathrm{LMP} 1^{\mathrm{WT}}$ and mutant $\mathrm{LMP} 1^{\Delta 232-351}$ transformed NP69 cells were investigated by proteomic analysis. The results of the present study revealed that 17 proteins were variably expressed in NP69-LMP1 ${ }^{\triangle 232-351}$-transduced cells compared with NP69-LMP1 ${ }^{\text {WT }}$-transduced cells. These results may provide notable information and insight for further research. Additionally, these differential proteins were associated with cellular metabolism, signal conduction, molecular chaperones, cellular structure, immunoregulation, transcription and translation, energy and electron, molecular chaperone, as reported in the present study. Furthermore, proteins were mainly located in the endochylema, cytochondriome, endoplasmic reticulum, nucleus and cell membrane. To investigate the expression levels of differential proteins, several proteins were analyzed by western blotting and RT-qPCR. The results were similar with outcomes identified by proteomics methods in the present study (Table III and IV).

G protein, namely guanosine 5'-triphosphate-binding protein, is an important protein associated with the regulation of cellular signal transduction. Zhou et al (20) demonstrated that $\mathrm{G}$ protein phosphorylation and modification accelerated cellular apoptosis. In the present study, compared with NP69-LMP $1^{\text {WT }}$, the expression levels of G protein were 
significantly increased within NP69-LMP1 ${ }^{\triangle 232-351}$ cells. Therefore, LMP1 may downregulate the expression of $\mathrm{G}$ proteins to induce minor activating proteins involved in apoptosis of NP69-LMP1 ${ }^{\text {WT }}$ cells. Hence, LMP1 may mediate cell proliferation associated with the expression of $\mathrm{G}$ proteins.

Heterogeneous nuclear ribonucleoprotein (hnRNP) was first described as a family of proteins that bind RNA polymerase II and is transcribed to form hnRNP particles. The hnRNP $\mathrm{A} / \mathrm{B}$ proteins are among the most abundant RNA-binding proteins, forming the core of the ribonucleoprotein complex that connects with nascent transcripts in eukaryotic cells. They also recruit regulatory proteins connected with pathways related to DNA and RNA metabolism (21). He et al (22). have shown that hnRNP A/B proteins are dysregulated in a large number of epithelial cancer cells In the present study, compared with NP69-LMP1 ${ }^{\text {WT }}$, the expression levels of G protein were significantly decreased within NP69-LMP1 ${ }^{\Delta 232-351}$ cells. This suggests that LMP1 may upregulate the expression of $\mathrm{G}$ proteins to induce activation of proteins involved in the proliferation of NP69-LMP1 ${ }^{\text {WT }}$ cells.

Isocitrate dehydrogenase is a rate-limiting enzyme of the tricarboxylic acid cycle and a key enzyme of cell energy metabolism, cell growth and proliferation (23). In the present study, the expression of isocitrate dehydrogenase was higher in NP69-LMP1 ${ }^{\text {WT }}$ than that in NP69-LMP1 ${ }^{\Delta 232-351}$. The cell growth and proliferation of NP69-LMP1 ${ }^{\text {WT }}$ was faster than NP69-LMP1 ${ }^{\Delta 232-351}$. The results of the present study suggest that LMP1-CTAR3 may mediate the regulation of isocitrate dehydrogenase expression, and affect cell metabolism and synthesis, which serves an important role in promoting cell proliferation and transformation (24).

Collectively, the findings of the present study suggested that LMP1 serves an important role in the transformation and proliferation of nasopharyngeal epithelial cells. The data of differential proteins was reported and 17 differential proteins were identified between NP69-LMP1 ${ }^{\text {WT }}$ and NP69-LMP1 $1^{\Delta 232-351}$-transduced cells. These differential proteins, associated with LMP1 and the domain of CTAR3, may be involved in the regulation of cell proliferation and transformation of nasopharynx epithelial cells. The findings provide novel insight for further NPC research and may be valuable for investigating the mechanism of LMP1-associated tumors. However, how LMPI and its CTAR3 active region regulate the expression of these differential proteins, as well as the mechanisms by which these differentially expressed proteins promote epithelial cell growth, proliferation and transformation, requires further investigation.

\section{Acknowledgements}

The authors would like to thank Dr Sai Wah Tsao (University of Hong Kong, Hong Kong, SAR, China) for NP69 cell lines.

\section{Funding}

The present study was supported by the Hunan Provincial Innovation Foundation For Postgraduate (grant no. CX2016B478), National Natural Science Foundation of China (grant no. 30470668) and Health Department Scientific Research Foundation of Hunan Province (grant no. B2006-100).

\section{Availability of data and materials}

All data generated or analyzed during this study are included in this published article.

\section{Authors' contributions}

ZWZ and HLZ performed the majority of the experiments in this work. YHY, ZCC and YMO performed research and analyzed the data. ZWZ, HLZ and ZMH wrote the manuscript. $\mathrm{XSH}$ and $\mathrm{ZMH}$ conceived the experimental design, were responsible for financial support and wrote the manuscript. All authors read and approved the final manuscript.

\section{Ethics approval and consent to participate}

Not applicable.

\section{Patient consent for publication}

Not applicable.

\section{Competing interests}

The authors declare that they have no competing interests.

\section{References}

1. Thompson MP and Kurzrock R: Epstein-Barr virus and cancer. Clin Cancer Res 10: 803-821, 2004.

2. Ma SD, Tsai MH, Romero-Masters JC, Ranheim EA, Huebner SM, Bristol JA, Delecluse HJ and Kenney SC: Latent membrane protein 1 (LMP1) and LMP2A collaborate to promote Epstein-Barr virus-induced $\mathrm{B}$ cell lymphomas in a cord blood-humanized mouse model but are not essential. J Virol 91: e01928-16, 2017.

3. Pandya $J$ and Walling DM: Oncogenic activity of Epstein-Barr virus latent membrane protein 1 (LMP-1) is down-regulated by lytic LMP-1. J Virol 80: 8038-8046, 2006.

4. Lavorgna A and Harhaj EW: EBV LMP1: New and shared pathways to NF-kB activation. Proc Natl Acad Sci USA 109: 2188-2189, 2012.

5. Ikeda O, Miyasaka Y, Yoshida R, Mizushima A, Oritani K, Sekine Y, Kuroda M, Yasui T, Fujimuro M, Muromoto R, et al: BS69 cooperates with TRAF3 in the regulation of Epstein-Barr virus-derived LMP1/CTAR1-induced NF-kappaB activation. FEBS Lett 584: 865-872, 2010.

6. Shkoda A, Town JA, Griese J, Romio M, Sarioglu H, Knöfel T, Giehler F and Kieser A: The germinal center kinase TNIK is required for canonical NF- $\kappa \mathrm{B}$ and JNK signaling in B-cells by the EBV oncoprotein LMP1 and the CD40 receptor. PLoS Biol 10: e1001376, 2012.

7. Gires O, Kohlhuber F, Kilger E, Baumann M, Kieser A, Kaiser C, Zeidler R, Scheffer B, Ueffing M and Hammerschmidt W: Latent membrane protein 1 of Epstein-Barr virus interacts with JAK3 and activates STAT proteins. EMBO J 18: 3064-3073, 1999.

8. Livak KJ and Schmittgen TD: Analysis of relative gene expression data using real-time quantitative PCR and the 2(-Delta Delta C(T)) method. Methods 25: 402-408, 2001.

9. Farrell PJ: Epstein-Barr virus and cancer. Annu Rev Pathol 14: 29-53, 2019.

10. Kilger E, Kieser A, Baumann M and Hammerschmidt W: Epstein-Barr virus-mediated B-cell proliferation is dependent upon latent membrane protein 1, which simulates an activated CD40 receptor. EMBO J 17: 1700-1709, 1998.

11. Shair KH, Schnegg CI and Raab-Traub N: EBV latent membrane protein 1 effects on plakoglobin, cell growth, and migration. Cancer Res 68: 6997-7005, 2008.

12. Tu C,Zeng Z, Qi P,Li X, Guo C, Xiong F, Xiang B, Zhou M, Liao Q, Yu J, et al: Identification of genomic alterations in nasopharyngeal carcinoma and nasopharyngeal carcinoma-derived Epstein-Barr virus by whole-genome sequencing. Carcinogenesis 39: 1517-1528, 2018. 
13. Tsao SW, Wang X, Liu Y, Cheung YC, Feng H, Zheng Z, Wong N Yuen PW, Lo AK, Wong YC and Huang DP: Establishment of two immortalized nasopharyngeal epithelial cell lines using SV40 large T and HPV16E6/E7 viral oncogenes. Biochim Biophys Acta 1590: 150-158, 2002.

14. Lo AK, Liu Y, Wang XH, Huang DP, Yuen PW, Wong YC and Tsao GS: Alterations of biologic properties and gene expression in nasopharyngeal epithelial cells by the Epstein-Barr virus-encoded latent membrane protein 1. Lab Invest 83: 697-709, 2003.

15. Ahsan N, Kanda T, Nagashima K and Takada K: Epstein-Barr virus transforming protein LMP1 plays a critical role in virus production. J Virol 79: 4415-4424, 2005.

16. Xin B, He Z, Yang X, Chan CP, Ng MH and Cao L: TRADD domain of Epstein-Barr virus transforming protein LMP1 is essential for inducing immortalization and suppressing senescence of primary rodent fibroblasts. J Virol 75: 3010-3015, 2001.

17. Gallardo-VeraF,DiazD,Tapia-Rodriguez M,Fortoul van derGoesT, Masso F, Rendon-Huerta E and Montaño LF: Vanadium pentoxide prevents NK-92MI cell proliferation and IFNg secretion through sustained JAK3 phosphorylation. J Immunotoxicol 13: 27-37, 2016.

18. Smirnova KV, Diduk SV, Senyuta NB and Gurtsevitch VE: Molecular biological properties of the Epstein-Barr virus LMP1 gene: Structure, function and polymorphism. Vopr Virusol 60: 5-13, 2015 (In Russian)

19. Uchida J, Yasui T, Takaoka-Shichijo Y, Muraoka M, Kulwichit W, Raab-Traub N and Kikutani H: Mimicry of CD40 signals by Epstein-Barr virus LMP1 in B lymphocyte responses. Science 286: 300-303, 1999.
20. Zhou C, Dai X, Chen Y, Shen Y, Lei S, Xiao T, Bartfai T, Ding J and Wang MW: G protein-coupled receptor GPR160 is associated with apoptosis and cell cycle arrest of prostate cancer cells. Oncotarget 7: 12823-12839, 2016.

21. He Y and Smith R: Nuclear functions of heterogeneous nuclear ribonucleoproteins A/B. Cell Mol Life Sci 66: 1239-1256, 2009.

22. He Y, Brown MA, Rothnagel JA, Saunders NA and Smith R: Roles of heterogeneous nuclear ribonucleoproteins A and B in cell proliferation. J Cell Sci 118: 3173-3183, 2005.

23. Lu HC, Ma J, Zhuang Z, Qiu F, Cheng HL and Shi JX: Exploring the regulatory role of isocitrate dehydrogenase mutant protein on glioma stem cell proliferation. Eur Rev Med Pharmacol Sci 20: 3378-3384, 2016

24. Bentz GL, Whitehurst CB and Pagano JS: Epstein-Barr virus latent membrane protein 1 (LMP1) C-terminal-activating region 3 contributes to LMP1-mediated cellular migration via its interaction with Ubc9. J Virol 85: 10144-10153, 2011.

(i)(9) This work is licensed under a Creative Common Attribution-NonCommercial-NoDerivatives 4.0 International (CC BY-NC-ND 4.0) License. 